\title{
SIKAP MASYARAKAT KOTA PADANGSIDIMPUAN TERHADAP PERKEMBANGANBEBERAPA TEMPAT WISATA \\ (Studi Kasus Objek Wisata Kaisar Waterpark Desa Joring Natobang Kecamatan Padangsidimpuan Angkola Julu)
}

\author{
Oleh : \\ Rosnida Siregar ${ }^{1)}$, Mariyatul Kubtiyah Ritonga ${ }^{2)}$ \\ ${ }^{1,2}$ Fakultas IPSB, Institut Pendidikan Tapanuli Selatan \\ email:siregarnida25@gmail.com
}

\begin{abstract}
Abstrak
Tujuan dari penelitian ini adalah untuk mengetahui sikap masyarakat terhadap perkembangan beberapa tempat wisata di Kota Padangsidimpuan. Tepatnya perkembangan objek wisata Kaisar Waterpark Desa Joring Natobang Kecamatan Padangsidimpuan Angkola Julu Kota Padangsidimpuan.Metode Penelitian yang dilakukan adalah metode survey dengan jumlah total populasi sebanyak 995 orang dan diambil sampel sebanyak 95 orang yang tersebar di 4 (Empat)dusun. Hasil penelitian menunjukkan bahwa terdapat pengaruh positif antara sikap masyarakat terhadap perkembangan objek wisata Kaisar Waterpark dengan nilai persamaan regresi linear sederhana sebesar $\mathrm{Y}=8,520+0,946 \mathrm{X}$. Hasil perhitungan koefisien determinasi $\left(\mathrm{R}^{2}\right)$ diperoleh nilai sebesar 0,981 yang menunjukkan besarnya pengaruh sikapmasyarakat terhadap perkembangan objek wisata yaitu 98,1 $\%$ dengan nilai koefisien korelasi (r) sebesar 0,990 yang berkategori sangat kuat. Dan sisanya sebesar 1,9\% dipengaruhi oleh variabel lain diluar penelitian ini. Sehingga ditarik kesimpulan masyarakat setuju dan mendukung pengembangan objek wisata kaisar waterpark dan dampak perkembangan objek wisata Kaisar waterpark terhadap masyarakat Desa Joring Natobang Kecamatan Padangsidimpuan Angkola Julu Kota Padangsidimpuan adalah meningkatnya pendapatan masyarakat dan berkurangnya pengangguran. Dimana para penjual atapun warung-warung yang berjualan di sekitar Kaisar Waterpark meningkat penghasilannya dan para pemuda pemudi seperti naposo nauli bulung diberdayakan bekerja di lokasi objek wisata Kaisar Water Park.
\end{abstract}

Kata kunci: sikap, masyarakat, objek wisata

\section{PENDAHULUAN}

Seperti tuntutan zaman yang terus berkembang seperti pada era globalisasi saat ini, sektor pariwisata merupakan kekuatan terbesar dan terkuat dalam pembiayaan dan menggerakkan perekonomian global. Perkembangan pariwisata di Indonesia saat ini sedemikian pesat. Oleh karena itu pemerintah indonesia terus berusaha memperhatikan sektor pariwisata. Adanya perkembangan pariwisata ini dapat membantu pemerintah dalam meningkatkan ekonomi serta mengurangi angka pengangguran. Perkembangan pariwisata juga diandalkan sebagai sektor penghasil devisa bagi negara. Begitu pula dengan Kota Padangsidimpuan Provinsi Sumataera Utara.

Kota Padangsidimpuan dikenal dengan istilah kota salak. Yang terdiri dari 6 Kecamatan seKota Padangsidimpuan. Yaitu Kecamatan Padangsidimpuan Angkola Julu, Padangsidimpuan Batunadua, Padangsidimpuan Hutaimbaru, Padangsidimpuan Selatan, tenggara dan Utara. Desa Joring Natobang sebagai lokasi penelitian terletak di Kecamatan Padangsidimpuan Angkola Julu. Dan sesuai dengan Data BPS Kecamatan Padangsidimpuan Angkola Julu Desa Joring Natobang memiliki tingkat perekekonomian yang lebih tinggi dari segi penghasilan pariwisata di bandingkan dengan desa lainnya di Kecamatan Padangsidimpuan Angkola Julu.
Dan secara umum Objek wisata di Kota Padangsidimpuan terdiri dari objek wisata alam dan objek wisata buatan. Beberapa diantaranya yaitu Tor Simarsayang yang terletak di Kelurahan Batang Ayumi Julu Kecamatan Padangsidempuan Utara, Puncak JB di Kecamatan Padangsidimpuan Tenggara dan Perkebunan buah naga di Padangsidimpuan Hutaimbaru. Sedangkan objek wisata buatan di Kota Padangsidimpuan yaitu Kolam renang siharang-karang yang beralamat di lembah lubuk manik kecamatan Padangsidimpuan Hutaimbaru, Kolam Libers di Kelurahan Padangmatinggi Kecamatan Padangsidimpuan Selatan dan Kaisar Waterpark yang berlokasi di Desa Joring Natobang Kecamatan Padangsidimpuan Angkola Julu. Peneliti membatasi masalah penelitian yaitu hanya mengkaji Kaisar Waterpark Desa Joring Natobang karena objek wisata ini merupakan tempat wisata favorit masyarakat secara umum karena mempunyai daya tarik dan keunikan tersendiri dibandingkan tempat wisatalainnya.

Sebagai salah satu objek wisata Kaisar Waterpark banyak dikunjungi wisatawan lokal karena mempunyai daya tarik yang unik khususnya di bagian fasilitas wisata.Kaisar Waterpark merupakan tempat wisata buatan berupa kolam renang dan sungai air terjun buatan yang dapat memukau pengunjung. Keterlibatan masyarakat sekitar dalam pengembangan tempat wisata Kaisar 
Waterpark menjadi hal yang penting karena masyarakat yang lebih mengetahui dan memahami akan potensi wilayahnya. Namun sikap masyarakat sekitar berbeda dalam merespon perkembangan tempat wisata.Hal ini dikarenakan masih kurangnya pemahaman masyarakat tentang kebijakan Pemerintah Daerah.Kebijakan yang dimaksudkan adalah aturan yang diterapkan oleh Pemerintah Daerah. Kebijakan tesrsebut berupa keterkaitan antara kehendak, tindakan, dan hasil.Pada kehendak, kebijakan terefleksikan pada sikap pemerintah.Sedangkan pada tingkat tindakan, kebijakan diartikan pada perilaku pemerintah, dan pada level hasil yaitu yang benar-benar dilakukan pemerintah.

Dalam menunjang keberhasilan pembangunan di Desa Joring Natobang sebagai program yang terencana berdasarkan kondisi sosial ekonomi masyarakat maka penetapan kebijakan Desa Joring Natobang mengacu pada kebijakan pemerintah Kota Padangsidimpuan diantaranya peningkatan ekonomi masyarakat dan pengelolaan potensi wisata.

Pariwisata terdiri dari kata wisata yang artinya perjalanan, kata wisatawan didefenisikan orang atau sekelompok orang yang melakukan perjalanan dalam kegiatan kepariwisataan. Sifat kegiatan pariwisata adalah sosial, ekonomi dan kebudayaan yang timbul sebagai efek dari perjalanan wisata.Sesuai dengan penjelasan tersebut pariwisata adalah berbagai macam kegiatan wisata yang didukung oleh berbagai fasilitas serta layanan yang disediakan masyarakat, pengusaha, Pemerintah dan Pemerintah Daerah untuk meningkatkan perekonomian.

Alasan peneliti menjadikan Kaisar Waterpark sebagai objek penelitian karena merupakan salah satu tempat wisata favorit masyarakat yang sedang berkembang di Kota Padangsidimpuan.Kaisar Waterpark merupakan objek wisata buatan berupa kolam renang yang memiliki fasilitas lengkap dan lokasinya berada di daerah pegunungan yang sejuk dan asri, hal ini yang membedakan Kaisar Waterpark dengan kolam renang lainnya.

Pada awal proses pengembangan objek wisata Kaisar waterpark tidak selalu mendapat respon positif dari masyarakat sekitar. Ada sebagian masyarakat disekitar objek wisata kaisar waterpark menyatakan kurang mendukung dengan adanya pengembangan tempat wisata tersebut. Hal ini dikarenakan bahwa masyarakat menganggap rupiah hasil dari pengembangan objek wisata akan dimanfaatkan oleh para pengelolanya sendiri tanpa memikirkan nasib masyarakat sekitar. Namun permasalahan tersebut segera diatasi dengan cara melakukan musyawarah antara kelempok pengelola tempat wisata dengan masyarakat sekitar serta aparat desa sebagaimediator.

Perkembangan objek wisata Kaisar waterpark tidak hanya membawa dampak positif

tetapi juga dampak negatif bagi
masyarakat.Banyaknya kunjungan wisatawan merupakan manfaat dari pariwisata karena dapat menambah pendapatan daerah serta memperluas kesempatan kerja.Manfaat tersebut sejalan dengan kerugian yang ditimbulkan akibat perkembangan tempat wisata.dampak negatifnya adalah ramainya lalu lintas, kumuhnya lingkungan dan perubahangayahidup. Berdasarkan alasan yang telah dikemukakan diatas peneliti tertarik untuk mengkaji penelitian dengan judul "Sikap Masyarakat Kota Padangsidimpuan terhadap Perkembangan Beberapa Tempat Wisata ("Studi kasus objek wisata Kaisar Waterpark Desa Joring Natobang Kecamatan Padangsidimpuan Angkola Julu”)

Tujuan penelitian ini adalah untuk menjawab pertanyaan : Bagaimana sikap masyarakat terhadap perkembangan objek wisata Kaisar Waterpark. Selanjutnya melalui penelitian ini diharapkan dapat membantu pemerintah daerah meningkatkan pendapatan daerah melalui perkembangan tempat wisata.

\section{Tinjauan Tentang Sikap Masyarakat Pengertian Tentang Sikap

$$
\text { Sri Utami Rahayuningsih }
$$
mengemukakan bahwa Sikap (Attitude) adalah : 1 . Berorientasi kepada respon, sikap adalah suatu bentuk dari perasaan, yaitu perasaan mendukung atau memihak (favourable) maupun perasaan tidak mendukung (unfavourable) pada suatu objek, 2 . Berorientasi kepada kesiapan respon : sikap merupakan kesiapan untuk bereaksi terhadap suatu objek dengan cara-cara tertentu, apabiladihadapkan pada suatu stimulus yang menghendaki adanya respon atau suatu pola prilaku, tendensi atau kesiapan untuk menyesuaikan diri dari situasi sosial yang telah terkondisikan.

Berdasarkan pendapat tersebut diatas peneliti menyimpulkan bahwa pengertian sikap (attitude) adalah perasaan, pikiran, dan kecenderungan seseorang yang kurang lebih bersifat permanen mengenal aspek-aspek tertentu dalam lingkungannya.

\section{Pengertian TentangMasyarakat}

Abdulsyani (2017) mengatakan bahwa masyarakat merupakan kelompok-kelompok makhluk hidup dengan realitas-realitas baru yang berkembang menurut hukum-hukumnya sendiri dan berkembang menurut polanya sendiri. Masyarakat dapat membentuk kepribadian yang khas bagi manusia, sehingga tanpa adanya kelompok manusia tidak akan mampu berbuat banyak dalam kehidupannya

Berdasarkan teori diatas penelitiberpendapat bahwa masyarakat adalah suatu kelompok manusia yang bekerja sama cukup lama dan saling mempengaruhi serta menganggap diri sebagai satu kesatuan serta mampu membentuk sebuah kebudayaan yang merupakan cerminan dari kebiasaan hidup sehari-hari mereka. 
Dan sesuai dengan pemaparan diatas Peneliti menyimpulkan bahwa sikap masyarakat adalah suatu tanggapan atau reaksi baik secara positif maupun negatif yang berasal dari sifat masyarakat secara langsung maupun tidak langsung bertujuan untuk memenuhi kebutuhan hidupnya, kebutuhan mempertahankan diri, dan memperjuangkan harapannya.

Tinjauan TentangPariwisata

Bukan saja masyarakat secara individu yang diuntungkan dengan pengembangan pariwisata, namun melalui pemerintah lokal (desa) peluang ekonomi pengembangan pariwisata ini juga dapat dikelola secara lebih baik melalui kelembagaan desa.Sifat kegiatan pariwisata adalah sosial, ekonomi, kebudayaan yang timbul sebagai efek dari perjalanan wisata.Pariwisata berkembang pesat dan menunjukkan pengaruh serta dampak yang luas di masyarakat dalam bidang ekonomi, sosial politik dan budaya, dan sebagainya.Oleh sebab itu, pariwisata tumbuh dan berkembang menjadi salah satu jenis industri baru yang mendorong pertumbuhan ekonomi dengan menyerap tenaga kerja, meningkatkan penghasilan, taraf hidup masyarakat dan mendorong tumbuhnya sektorsektor produksi terkait lainnya.

\section{Tinjauan Tentang Kaisar WaterPark}

Kaisar Waterpark merupakan objek wisata buatan jenis wisata tirta dengan fasilitas berupa kolam renang dengan memanfaatkan wahana air seperti seluncuran, air mancur, terowongan air dan sungai air terjun buatan.Fasilitas lainnya yang tersedia yaitu pondok-pondok kayu sebagai tempat duduk para wisatawan untuk menikmati keindahan alam yang lokasinya di pinggir sawah masyarakat sekitar.Selanjutnya ayunan besi sebagai tempat duduk sekaligus ayunan untuk pengunjung, tempat mandi bola untuk anak-ank dan patung hewan di sekitar taman sebagai tempat selfi pengunjung. Udara di sekitar lokasi rekreasi sangat sejuk karena posisinya yang tepat berada di lereng pegunungan Lubuk Raya serta aliran sungai Desa Joring Natobang. Fasilitas tambahan yaitu berupa fasilitas hiburan yang disediakan pengelola dengan mengundang artis lokal maupun ibu kota pada hari libur khusus seperti tahun baru dan lebaran untuk menghibur para pengunjung. Sarana, fasilitas dan hiburan menjadi prioritas utama pengelola wisata tersebut.

Dan ada satu hal lagi yang menjadi poin plus Kaisar Waterpark yang berbeda dengan kolam renang lainnya di Kota padangsidimpuan yaitu selain lokasinya yang memang berada di daerah pegunungan yang sejuk dan asri, sumber air di kolam ini ternyata berasal dari mata air pegunungan langsung dan tanpa kaporit.Pemilik sekaligus pengelola Kaisar Water Park adalah Bapak AKBP Parluatan Siregar beserta istrinya Ny Sandradewi Parluatan Gelar Namora Pardomuan Parluatan Siregar.Bapak Parluatan Siregar merupakan putra asli daerah yang berhasil diperantauan dan berinisiatif membangun kampung halamannya melalui pengembangan objek wisata KaisarWaterpark.

Saat wawancara awal peneliti dengan $\mathrm{Ny}$ Sandradewi selaku pengelola Kaisar Waterpak beliau berkomentar, selama libur panjang di akhir tahun atau menjelang awal tahun baru Kaisar Water Park selalu ramai dikunjungi wisatawan lokal yang datang dari berbagai daerah khususnya di Tapanuli Bagian Selatan (Tabagsel) maupun dari Kabupaten/Kota tetangga seperti Kota Sibolga dan Kabupaten Tapteng. Adapun skema kerangka berpikir dalam Penelitian ini adalah sebagai berikut

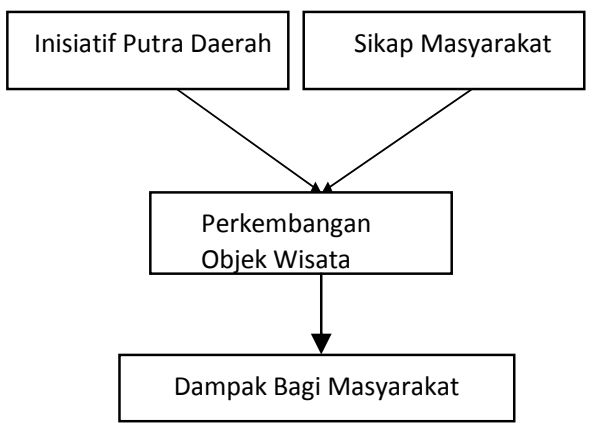

Kerangka pikir merupakan alur berfikir peneliti dalam penelitian.Kerangka pikir dalam penelitian ini, penulis membahas permasalahan pokok yang telah dirumuskan. Pembahasan tersebut akan dijelaskan dengan menggunakan konsep dan teori yang ada hubungannya untuk menjawab masalah penelitian. Adapun masalah dalam penelitian ini adalah bagaimana sikap masyarakat kota Padangsidimpuan terhadap perkembangan beberapa tempat wisata (studi kasus Objek Wisata Kaisar Waterpark Desa Joring Natobang Kecamatan Padangsidimpan Angkola Julu).

Penelitian ini terdiri dari dua variabel, dimana variabel $\mathrm{X}$ yaitu sikap masyarakat sebagai variabel independent sedangkan variabel $\mathrm{Y}$ yaitu perkembangan objek wisata sebagai variabel dependent.Penelitian ini di awali oleh adanya inisiatif dari putra daerah untuk mengembangkan potensi wisata di desa tersebut, objek penelitiannya adalah masyarakat yang ada di Desa Joring Natobang Kecamatan Padangsidimpuan Angkola Julu. Dalam mengembangkan suatu tempat wisata sangat dibutuhkan sikap dari masyarakat yang bertujuan untuk menentukan langkah yang akan diambil oleh pengelola dalam mengembangkan tempat wisata.

Pada variabel perkembangan objek wisata diartikan sebagai keadaan yang menggambarkan bagaimana perubahan sebuah objek wisata yang ada disuatu daerah.

\section{METODOLOGI PENELITIAN}

Penelitian ini menggunakan metode survei.Menurut pendapat Hamdi dan Bahrudin 
(2014) menyatakan Metode survei digunakan untuk mengumpulkan informasi berbentuk opini dari sejumlah orang terhadap topik atau isu tertentu. Tujuan dari survei adalah mengetahui gambaran umum karakteristik dari populasi.

\section{Metode PengumpulanData}

Populasi dalam penelitian ini berjumlah 995 orang.Sampel yang ditetapkan dalam penelitian ini sebanyak 95 Orang. Sedangkan teknik pengumpulan data utama dilakukan dengan cara menyebar angket dan tekhnik pengumpulan data pendukung dengan cara observasi, wawancara dan dokumentasi.

\section{Metode AnalisisData}

Data yang diperoleh dari hasil penelitian ini dianalisis dengan menggunakan analisis statistik deskriptif. Menurut Sugiyono, (2012) Statistik deskriptif adalah statistik yang digunakan untuk menganalisis data dengan cara mendeskripsikan atau menggambarkan data yang telah terkumpul sebagaimana adanya tanpa bermaksud membuat kesimpulan yang berlaku untuk umum atau generalisasi Hasil analisis deskriptif tersebut digunakan sebagai dasar untuk Uji Hipotesis. Namun, sebelum dilakukan penelitian hipotesis maka terlebih dahulu dilakukan uji asumsi dasar yang terdiri dari uji normalitas data, uji linearitas data dan uji homogenitas data dengan menggunakan software SPSS versi21.0.

\section{HASIL DAN PEMBAHASAN \\ Gambaran Umum Dan LokasiPenelitian}

Pada bagian ini dideskripsikan profil KecamatanPadangsidimpuan Angkola Julu yang meliputi kondisi geografis, topografi dan potensi Desa Joring Natobang.Deskripsi ini diharapkan dapat memberikan gambaran tentang berbagai hal yang mendasari perkembangan Desa Joring Natobang, Kecamatan Padangsidimpuan Angkola Julu Kota Padangsidimpuan.

Letak Dan Geografis Kecamatan Padangsidimpuan Angkola Julu

Luas Wilayah Kecamatan Padangsidimpuan Angkola Julu : 28,18 km2 dengan Ketinggian di atas Permukaan Laut : 370 - 1100 meter Terletak Pada :

Lintang Utara : 1o 22I 03II

Bujur Timur : 99o 14I 0,44II

Berbatasan dengan:

Sebelah Utara : Kab. Tapanuli Selatan

Sebelah Selatan : Kec.Padangsidimpuan Utara

Sebelah Barat : Kab. Tapanuli Selatan

Sebelah Timur : Kec. Padangsidimpuan Batunadua Suhu : Antara 24-300C dan beriklim tropis

Selanjutnya adalah peta wilayah Kecamatan Padangsidimpuan Angkola Julu Kota padangsidimpuan. Berikut gambar peta wilayah tersebut.
Peta Wilayah Kecamatan Padangsidimpuan Angkola Julu

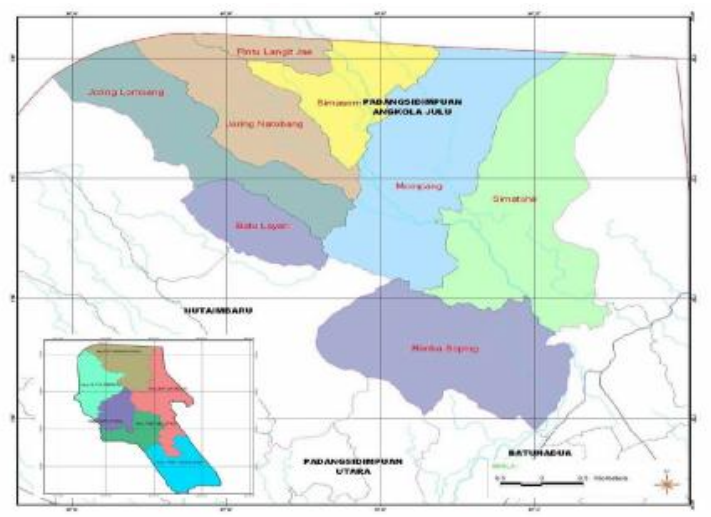

Sumber : BPS dalam angka 2018

Tabel berikutnya adalah luas wilayah desa di Kecamatan Padangsidimpuan Angkola Julu Kota Padangsidimpuan dilihat dari luas wilayah dan persentase rasionya.

Tabel 3.1: Luas Wilayah dan rasio terhadap luas kecamatan menurut desa/kelurahan, 2018

\begin{tabular}{|l|l|l|}
\hline Desa/ Kelurahan & $\begin{array}{l}\text { Luas } \\
\text { Wilayah } \\
\text { (Km2) }\end{array}$ & Rasio \% \\
\hline \multicolumn{1}{|c|}{2} & 3 \\
\hline Simatohir & 5,28 & 18,74 \\
\hline Rimba Soping & 4,24 & 15,05 \\
\hline Mompang & 4,96 & 17,60 \\
\hline Batu layan & 1,30 & 4,61 \\
\hline Joring Lombang & 2,94 & 10,43 \\
\hline Joring Natobang & 2,47 & 8,77 \\
\hline Simasom & 1,92 & 6,81 \\
\hline Pintu Langit Jae & 5,07 & 17,99 \\
\hline Jumlah & $\mathbf{2 8 , 1 8}$ & $\mathbf{1 0 0 , 0 0}$ \\
\hline
\end{tabular}

Sumber : BPS Kecamatan Padangsidimpuan Angkola Julu dalam angka 2018

Sejarah Singkat Desa joring Natobang Kecamatan Padangsidimpuan Angkola Julu

Desa Joring Natobang di pimpin oleh Bapak Andi Aryanto Harahap sejak tahun 2018. Yang terdiri dari 4 (empat) dusun dengan jumlah masyarakat sekitar 995 orang.

\section{Sarana danPrasarana}

Mayoritas lahan di Desa Joring Natobang dimanfaatkan untuk permukiman masyarakat dan persawahan atau perkebunan.Beberapa sarana dan prasarana dibangun untuk menunjang kegiatan dan perkembangan masyarakat, seperti sarana kesehatan, pendidikan, dan sarana ibadah.

\section{Pembangunan Desa}

Program Desa Joring Natobang dilaksanakan dengan mengacu pada strategistrategi yang disusun berdasarkan kondisi sosial ekonomi masyarakat. Dalam menunjang keberhasilan pembangunan di Desa Joring Natobang sebagai program yang terencana berdasarkan kondisi sosial ekonomi masyarakat 
maka penetapan kebijakan Desa Joring Natobang mengacu pada kebijakan pemerintah Kota Padangsidimpuan.

\section{KebijakanUmum}

Dalam menunjang keberhasilan pembangunan di Desa Joring Natobang, maka ditetapkan kebijakan yang mengacu pada kebijakan daerah Kecamatan Padangsidimpuan Angkola Julu, maka arah kebijakannya adalah peningkatan Ekonomi Masyarakat.

a. Meningkatkan pendapatan dan kesejahteraan masyarakat.

b. Mengembangkan usaha agrobisnis.

c. Meningkatkan kesejahteraan masyarakat.

d. Pengelolaan potensiwisata.

e. Peningkatan Pemberdayaan Masyarakat.

f. Memberdayakan masyarakat dalam usaha pembangunan ekonomi masyarakat.

g. Pemberdayaan lembaga sosial dan pendidikan masyarakat utuk menunjang pembangunan.

h. Memberdayakan masyarakat dalam meningkatkan partisipasi masyarakat

\section{PENUTUP}

\section{a. Kesimpulan}

Berdasarkan hasil penelitian dan pembahasan sikap masyarakat Kota Padangsidimpuan terhadap perkembangan objek wisata kaisar waterpark, yaitu di Desa Joring Natobang, Kecamatan Padangsidimpuan Angkola Julu Kota Padangsidimpuan, dan berdasarkan analisa melalui uji regresi linear sederhana yang telah dilakukan dengan menggunakan program software SPSS versi 21.0, maka diperoleh kesimpulan sebagai berikut:

Berdasarkan hasil pengamatan dan hasil penelitian mengenai sikap masyarakat terhadap perkembangan Objek Wisata Kaisar WaterparkDesa Joring Natobang Kecamatan Padangsidimpuan Angkola Julu sebagian besar responden mengungkapkan bahwa masyarakat sekitar objek wisata setuju dan mendukung atas perkembangan objek wisata.Hal ini dikarenakan objek wisata Kaisar Waterpark dapat dijadikan wisata andalan diKecamatan Padangsidimpuan Angkola Julu.Mengingat Kecamatan Padangsidimpuan Angkola Julu belum mempunyai objek wisata andalan maka objek wisata Kaisar Waterpark ini sangat cocokuntukdijadikantempatwisataandalan.Perkemb anganobjek wisata ini juga merupakan hasil kerjasama yang baik antara pengelola objek wisata,masyarakat Desa Joring Natobang, aparat desa serta Dinas Pariwisata.

\section{b. Saran}

Dalam rangka penyempurnaan hasil penelitian atau kesimpulan serta mengoptimalkan sikap masyarakat terhadap perkembangan objek wisata Kaisar Waterpark maka dapat dirumuskan beberapa saran dalam penelitian ini antara lain:

1. Bagi Pengelola Objek Wisata
Mempertahankan atau meningkatkan kreativitas agar dapat mengembangkanObjek Wisata Kaisar Waterpark lebihbaik lagi, serta tetap menjaga kelestarian alam.Dan menjalin hubungan baik dengan masyarakat selaku stakeholder yang paling berperan dalam perkembangan objekwisata.

2 BagiPemerintah

Dapat melakukan pengawasan dan kerja sama yang baik bersama dengan masyarakat dan juga pengelola Objek Wisata Kaisar Waterpark, seperti mengadakan pelatihan tentang manajemen kepariwisataan agar tempat wisata dapat dikelola denganbaik dan terus meningkat.

3. Bagi Kepala Desa Sebagai Pemerintah Daerah Menerapkan aturan resmi tentang etika masyarakat terhadap pengunjung maupun sebaliknya dalam bersosialisasi, membuat aturan tentang pemberhentian hiburan keyboard pada jam pelaksanaan ibadah, dan pemberdayaan masyarakat sekitar seperti muda-mudi dalam aktivitas yang dilaksanakan objek wisata kaisar waterpark.

4. Bagi Masyarakat

Khususnya masyarakat Desa Joring Natobang seharusnya bekerjasama dan mendukung pengembangan objek wisata Kaisar Waterpark misalnya dalam hal promosi, dan menghimbau masyarakat sekitar untuk menjaga keamanan dan ketertiban objek wisata Kaisar Waterpark.

\section{UCAPAN TERIMAKASIH}

Terimakasih kepada Kemesristek Dikti melalui Simlitabmas dari DP2M DIKTI yang telah memberikan dana dalam penelitian ini untuk pendanaan tahun 2019.

\section{DAFTAR PUSTAKA}

Abdulsyani, 2007.Sosiologi Skematika, Teori dan Terapan. Jakarta: Bumi Aksara.

http://www.sumutprov.go.id/berita-lainnya/1555gubsu-harapkan-kolam-renang-padangsidempuan-lahirkan-atlet-berprestasi.

Hamdi, A. S dan E. Bahrudin.2014. Metode Penelitian Kuantitatif Aplikasi dalam Pendidikan. Deepublish, Yogyakarta.

Kecamatan Padangsidimpuan Angkola Julu dalam angka 2018, Badan Pusat Statistik Kota Padangsidimpuan.

Pangestuti,2018, Skripsi, Respon masyarakat terhadap perkembangan tempat wisata Hutan Kota Bukit Pangonan.

Rusdan dkk (2014), Persepsi dan Sikap Masyarakat Lingkar Gunung Rinjani Terhadap Industri Pariwisata (Suatu Upaya Menyongsong Rinjani sebagai Geopark Dunia), Laporan Penelitian, Magister Manajemen, Univ. Mataram.

Sri Utami Rahayuningsih. 2008. Sikap (Attitude) (Online) http:// www. Atttitude,blogspot. Com, diakses 22 April 2019.

Selo Soemardjan, 2009. Perubahan Sosial di Yogyakarta. Jakarta: Komunitas Bambu. 